\title{
Supporting SMEs through government purchasing activity
}

\author{
Kim Loader
}

\begin{abstract}
As major consumers of goods and services, governments have an opportunity to support SMEs directly through their purchasing policies. This study examines the experience of SMEs in the north-east of England in their attempt to supply UK public sector organizations, and finds that, despite recent initiatives, barriers are being experienced by the majority of SMEs surveyed. The findings suggest that both government and small business sectors face challenges, such as resolving policy conflicts, managing resource demands and facilitating organizational change, in overcoming these barriers. Further investigation is required to inform the resolution of these demands.
\end{abstract}

Keywords: procurement; public sector; purchasing; SMEs; UK

The author is with the Teesside Business School, University of Teesside, Borough Road,

Middlesbrough TS1 3BA, UK. Tel: +44 1642 342838. Fax: +44 1642342925.

E-mail: K.Loader@tees.ac.uk.

Governments are major consumers of goods and services and present an important market opportunity for all businesses (Business Link, 2003). Whilst government support of small firms can take on a number of guises, such as reducing the burden of legislation faced, providing advice, and helping with finance, the UK government has recently recognized that one good means of providing direct support to small and mediumsized enterprises (SMEs) is through its purchasing policies, and has placed SME supply opportunities on its procurement agenda. The scale of government business in the UK is immense: local government spends $£ 25$ billion a year on goods and services (Business Link, 2003 ), central civil government about $£ 13$ billion, Ministry of Defence $£ 9$ billion and health over $£ 3.5$ billion (Office of Government Commerce and Business Link, 2003). However, whilst the size of the market is clearly considerable, what is of interest to small businesses is whether or not they are able to obtain a share. Some reassurance may be provided by the Office of Government Commerce (OGC), which recently stated its commitment 'to making the government marketplace more attractive to suppliers and reducing the barriers for smaller organisations' (OGC, 2003, p 22).
The aim of this study is to examine the role of government in directly supporting small businesses through purchasing policies and practices. Focusing upon the experiences gained in the UK, the study aims to determine whether government purchasing policies can successfully support SMEs, and does so by focusing upon the SME perspective. This is provided by investigating the current experience of small firms in their attempts to supply government. The paper begins by outlining developments in procurement policy and practice in the UK public sector. The relevance of these developments is discussed in relation to SMEs before the presentation and examination of empirical evidence obtained from a sample of SMEs. Finally the implications of the findings for government and small business sectors are considered and conclusions drawn.

\section{Developments in UK government procurement}

Procurement policy and practice within public sector organizations (PSOs) has received an increasing amount of attention from the UK government in recent years and has also become the subject of practitioner and 
Table 1. Developments in public sector purchasing.

\begin{tabular}{|c|c|c|}
\hline Year & Report/initiative & Themes \\
\hline 1984 & $\begin{array}{l}\text { Government Purchasing: A Multi-Department } \\
\text { Review of Government Contract and } \\
\text { Procurement Procedures, Cabinet Office }\end{array}$ & $\begin{array}{l}\text { The primary objective of government purchasing is to 'provide the } \\
\text { accounting officer, and through him Parliament and the taxpayer, with } \\
\text { value for money from expenditure on procurement' (para 1.4) }\end{array}$ \\
\hline 1995 & $\begin{array}{l}\text { White Paper, Setting New Standards: } \\
\text { A Strategy for Government Procurement }\end{array}$ & $\begin{array}{l}\text { Primary objective is value for money: 'the optimum combination of } \\
\text { whole life costs and quality to meet the customers requirements' } \\
\text { (HM Treasury, 1995, pp 2-3) } \\
\text { Partnership: 'Departments will work together with suppliers to secure } \\
\text { improvements in the performance of both parties. Although they will } \\
\text { press suppliers to reduce cost and improve quality, they will recog- } \\
\text { nise that mutually satisfactory relationships are in the interests of } \\
\text { both sides and will avoid an unnecessarily adversarial approach' (HM } \\
\text { Treasury, 1995, p13). } \\
\text { Interdepartmental cooperation on procurement }\end{array}$ \\
\hline 1998 & $\begin{array}{l}\text { Efficiency in Civil Government Procurement, } \\
\text { Treasury/Cabinet Office }\end{array}$ & $\begin{array}{l}\text { 'All procurement of goods and services should be based on value for } \\
\text { money' (HM Treasury/Cabinet Office, para 2) } \\
\text { Strategic purchasing } \\
\text { Cooperation } \\
\text { Collaboration }\end{array}$ \\
\hline 1999 & $\begin{array}{l}\text { Modernising Civil Government Procurement, } \\
\text { The Gershon Report }\end{array}$ & $\begin{array}{l}\text { Value for money } \\
\text { Proposed the creation of the Office of Government Commerce }\end{array}$ \\
\hline 1999 & Modernising Procurement, National Audit Office & $\begin{array}{l}\text { Value for money } \\
\text { Collaboration with suppliers }\end{array}$ \\
\hline 1999 & Government Procurement Website established & \\
\hline 1999 & Government Procurement Service created & \\
\hline 2000 & Office of Government Commerce established & $\begin{array}{l}\text { Role: 'working with civil government as a catalyst to achieve best value } \\
\text { for money in commercial activities' (OGC, 2000, p 12) }\end{array}$ \\
\hline
\end{tabular}

for money in commercial activities' (OGC, 2000, p 12)

\section{Table 2. Features of the traditional and modern approaches to purchasing.}

\section{Traditional approach}

Price is the dominant decision factor

This approach typically is short-term in nature

The approach is typified by an adversarial relationship between purchaser and supplier, an arm's-length relationship

Suppliers are sought through competition

Competition is open and should not be influenced by past performance

There is likely to be multiple sourcing

There is little information exchange between parties

Trust not required

\section{Modern approach}

Cost, value and quality all are significant to the decision

Long-term relationship development with suppliers

Partnership is advocated; relationships are collaborative and cooperative

Supplier sourcing can take a variety of forms

This approach produces a narrower supply base

Knowledge sharing is key

Built upon trust

Notes: see, for example: Axelsson et al (2002), Briscoe et al (2001), Lamming (1993), McAleer et al (2000).

academic debate. Significant developments are summarized in Table 1. The first major report into purchasing was the 1984 review of purchasing procedures published by the Cabinet Office (Murray, 2002). This review explicitly identified that the primary objective of government purchasing was 'to provide the accounting officer, and through him Parliament and the taxpayer, with value for money from expenditure on procurement' (Cabinet Office, 1984, para 1.4). A gap of over 10 years then elapsed before the next significant contribution, the 1995 White Paper, Setting New Standards: A Strategy for Government Procurement (HM Treasury, 1995). 
Although value for money remained the primary objective, it was to be achieved by a greater focus on interdepartmental cooperation and a move towards partner-based supply relations, as being seen in the private sector.

Within the private sector the dominant procurement model in the 1970s was adversarial and competitive, but by the 1990 s, an alternative collaborative, or partnership, model emerged (Morrissey and Pittaway, 2004; McAleer et al, 2000). Each model is characterized by a set of features, summarized in Table 2. Whilst there would appear to be agreement over the main elements of each model, there is debate over the attributes of each and their contribution to successful procurement.

Criticisms of the traditional approach include the domination of price in the procurement decision, the higher cost and exposure to risk from frequent tendering, adversarial relations between buyers and suppliers with a resultant lack of trust, and poor information because of a reluctance among parties to share information (Lamming, 1993). However, counter-arguments advocate the benefits of an open competitive process: better prices; lower risk, as poor suppliers can more easily be replaced; enhanced quality through suppliers' learning and innovation, driven by a desire to win future contracts; and finally, it is argued that trust can develop, especially if repeat business is sought (Parker and Hartley, 1997; Erridge and Greer, 2002).

The partnership model similarly produces mixed arguments. Lamming (1993) sees it as providing solutions to many of the criticisms levelled at the traditional model, but recognizes that 'cooperation is essential' and that 'efficient information exchange is of fundamental importance' to its success (p 170). However, it is argued that the costs may be greater. An unsuccessful partnership would incur the additional costs of finding and establishing a new partnership (McAleer et al, 2000). Also, if potential suppliers are excluded, say because of favouritism, competition may be reduced, again with the consequence of increasing costs (Erridge and Greer, 2002). Finally the issues of trust and power are raised. Whilst partnership sourcing does not necessarily lead to single sourcing (Lamming, 1993), it is accepted that there will be a reduction in the number of suppliers. Parker and Hartley (1997) raise the concern that this may lead to suppliers behaving opportunistically, clearly an abuse of the trust relationship advocated. Alternatively, buyers may possess greater economic power compared with their suppliers, producing unequal power in the partnership. This is a concern that is particularly relevant to this examination of public sector procurement relationships with SMEs.

The 1995 White Paper was followed relatively quickly by the publication in 1998 of Efficiency in Civil
Government Procurement, and in 1999 by Modernising Civil Government Procurement, known as the Gershon Report. Both the 1998 and 1999 reports continued to state government procurement policy to be the achievement of value for money. However, the need for cross-departmental collaboration and joint procurement initiatives, placing PSOs in a stronger buying position and better able to achieve value for money, as well as improved supplier relationships, continued to be themes. Partly as a result of these reports, public sector procurement has seen other practical developments take place, including in 2000, the creation of the OGC.

Whilst value for money remains the primary driver in UK public sector procurement decisions, the broader policy intentions of greater collaboration with suppliers and more cross-departmental joint procurement initiatives are seen to be significant, changing both 'the nature of the procurement function' and 'the relationship between government department and suppliers' (Erridge and Greer, 2002, p 505). However, despite these changes public sector purchasing must take place within a legislative framework that requires supplier selection to be rigorous and to stand up to scrutiny. Whilst it can be argued that the resulting procedures tend towards the traditional adversarial model (Burnes and Anastasiadis, 2003), it appears that the UK public sector employs a hybrid approach, seeking advantages in cost, buyer power and improved relationships with its suppliers.

\section{UK government procurement policy and SMES}

As stated in the introduction, the UK government sees an opportunity to help small business through its role as a major consumer of goods and services. Specifically, it wishes to encourage SMEs to consider supplying PSOs by reducing the barriers they face. Various initiatives are in place, mainly focusing on the provision of information and advice. The Small Business Service (SBS) and the OGC have been jointly responsible for producing documentation for PSOs, to encourage their consideration of SMEs in purchasing arrangements (OGC and SBS, 2001a). They have also produced a booklet targeted towards SMEs to advise them on how to tender successfully for public sector contracts (OGC and SBS, 2001b). Since then a joint venture between OGC and Business Link has led to the development of electronic support in the form of a dedicated Web portal for suppliers to government. The importance of these schemes and the amount of concern about the issue is demonstrated by the joint publication of a critical report in 2003 by two further agencies, the Better Regulation Task Force (BRTF) and Small Business Council (SBC) in which they concluded that: 
we were surprised at the extent to which they (SMEs) are overlooked in public sector procurement. To exclude them or to make it difficult for them to compete in public sector markets makes no sense at all, particularly when the Government spends $£ 2.5$ billion annually on small business support services. What it gives with one hand it effectively takes away with the other by denying small firms opportunities to sell to the public sector (BRTF and SBC, 2003, p 3).

Fairness to SMEs is further encouraged by the government's Code of Good Customer Practice, which states that 'new players, including small and medium enterprises, are encouraged to bid for appropriate work' (OGC, 2001, p 4).

However, alongside these initiatives, PSOs are still required to base their procurement decisions on value for money, and are being encouraged to engage in jointcollaboration initiatives. An arm of the OGC, OGCbuying.solutions, has a specific role to assist in the achievement of value for money. Recognizing that 'in purchasing, size can matter', it aims to achieve value for money by maximizing the buying power of the public sector through closer collaboration and 'aggregation of requirements' (OGC, 2003, p 20). However, such aggregation is likely to create contracts beyond the capacity of SMEs. Only through the establishment of consortia or engaging in subcontract work can SMEs realistically obtain work if these conditions prevail. This situation is acknowledged by the UK government. However, SMEs are advised that 'there is no single way of finding out about subcontracting opportunities' (OGC and SBS, 2001b, p 7). They have to rely on receiving information from PSOs about their main contractors, or identifying them through publications such as the Official Journal of the European Community. Neither is there guidance on the establishment of consortia. However, other research, although focusing upon the establishment of consortia by SMEs for purchasing rather than supply, suggests that SME characteristics and attitudes create challenges hindering their success (Quayle, 2002; Morrissey and Pittaway, 2004).

The other trend identified in UK public sector procurement is the move towards partnership. Evidence from the construction industry, traditionally adversarial in its relationships, like the UK public sector, suggests that whilst SMEs view partnerships as potentially beneficial, they feel that enormous shifts in attitude will be required by them and especially by the other partners (Briscoe et al, 2001).

It should also be stated that in addition to wishing to support SMEs through its role as a consumer, the UK government acknowledges that SMEs can bring a number of benefits to the procurement process such that they 'may offer better value for money than larger suppliers' (OGC and SBS, 2001a, p 5).

\section{Method}

The study examines the experiences of small businesses located within the Teesside region in the north-east of England. Teesside was chosen after the subject of SMEs' ability to supply the UK public sector first came to attention during the pilot phase of a European-funded project that took place at the University of Teesside during 1998/99. The project sought to improve the competitiveness of SMEs in the region, in part by improving their success rate in supplying PSOs. Whilst the main phase of the funded project later took a turn towards training issues, the pilot phase had determined that SMEs did feel that they faced barriers compared with larger firms, although a number of approaches were being taken by PSOs to try to encourage small firms to tender for supply contracts. The determination by a locally based government agency, the Learning and Skills Council, in 2002, of difficulties in attracting SMEs to submit tenders for local council construction contracts demonstrated that an SME tendering deficit still existed and that there was a need to explore the issue further.

In this initial stage of the study, a postal survey has been adopted as the most appropriate method to collect as many SME views as possible and to provide a snapshot of the state of SME-public sector supply relationships. The questionnaire was developed from a review of recent policy and research literature and the findings of the earlier European-funded project. It sought to determine data about the extent of SME supply to public sector organizations and to elicit views about the nature of that supply, for example associated benefits and the existence of barriers thought to place SMEs at a disadvantage in their quest to become suppliers. The questionnaire was sent, in 2003, to 283 randomly selected small and medium-sized businesses located in the Teesside area in the north-east of England. In this sample the only criteria were location and size, adopting the generally accepted convention of an SME having up to 250 employees. No attempt was made to pre-select organizations by anticipating their appropriateness as suppliers to the public sector. Whilst 14 businesses returned uncompleted questionnaires, for reasons of inapplicability or lack of interest, usable replies were received from 109 firms, providing an acceptable response rate of $39 \%$. Although it is not the intention within this paper to analyse responses according to sector, it is worth noting that a broad range of sectors was represented: manufacturing, construction, transport, service and professional. Whilst some respondents were unable to answer every question, the questionnaires were materially complete.

A mixture of both open and closed questions was 
asked to provide an opportunity for respondents to air their views, whilst also providing useful quantitative data for frequency analysis. Many respondents did include useful comments and observations, which are reported in the next section.

\section{Survey findings and discussion}

\section{Level of supply}

The questionnaire first attempted to determine the level of supply by SMEs to public sector organizations, and SME views about the benefits associated with such a relationship. The survey found that $60 \%$ of respondents currently supplied public sector organizations. Clearly a majority, this indicates a level of success. However, this level has decreased from the $70 \%$ of firms that had previously engaged in supplying the public sector. It is also well below the $76 \%$ of respondents expressing a desire to start or continue supplying goods and services. Only $7 \%$ of firms stated that they did not wish to supply the public sector, and $17 \%$ were indifferent, with no sectoral pattern evident. This response suggests that public sector organizations are attractive customers to small businesses and that it is appropriate for the UK government to encourage SMEs as suppliers.

\section{Public sector as customer}

The attractiveness of supply may result from benefits that PSOs can offer as a customer. SMEs' opinions were sought on three benefits identified by public sector purchasing officers in the previous project work: certainty of payment, speedier payment and greater security over the longer term. Table 3 summarizes the responses.

Perhaps not surprisingly, certainty of payment is perceived to be the major benefit. Speed of payment received a mixed response, with opinion fairly equally divided. This should be disappointing to government, which requires that public sector organizations, as well as being 'fair, honest and professional', have 'to pay promptly and in line with agreed contract terms' (OGC and SBS, 2001b, p 2). Security was also divided more than may have been expected, perhaps reflecting the extent of recent change and development in the public sector. Views on other benefits were also sought and a range of views was expressed. The most common was the perception of prestige attached to the work, and the opportunity for promotion this created. There was also an appreciation of regular orders and continuity of work.

\section{Barriers}

The UK government would like small businesses to receive equal consideration in procurement decisions,
Table 3. Benefits to SMEs supplying PSOs.

\begin{tabular}{lccc}
\hline Benefit & Yes (\%) & No (\%) Unable to comment \\
& & & $\begin{array}{c}\text { (\%) } \\
\text { Certainty of payment }\end{array}$ \\
Speedier payment & 41 & 13 & 6 \\
Security over longer term & 61 & 44 & 9 \\
\hline
\end{tabular}

but it recognizes that 'many potential suppliers, including small firms, may be discouraged from tendering for public sector contracts because of a number of perceived or real barriers' (OGC and SBS, 2001a, p 4), leading to the SME tendering deficit referred to earlier. This view is supported by the data collected for this study. Although a majority of businesses are currently supplying the public sector, more (67\%) expressed the view that barriers existed. Interestingly, of the $67 \%$ who felt that barriers existed, $60 \%$ were current suppliers, $40 \%$ were not. Whilst this seems to confirm the need to address both perceived and real barriers, it may also be interpreted as indicating that the existence of barriers is more a perception than actual fact.

More detail on the type of barriers was sought. A range of barriers was listed and respondents who had expressed a view that barriers existed were asked to indicate all those that applied. Table 4 shows the response frequency for each barrier listed.

The barrier that features most is a lack of awareness of opportunities. This was an issue addressed further when the whole sample of SMEs was asked whether they were aware of information or events to encourage SMEs to tender for public sector contracts. Eighty-one per cent replied negatively. Specifically, they were asked whether they were aware of the document Tendering for Government Contracts. A Guide for Small Businesses (OGC and SBS, 2001b). Only 8\% claimed to be aware of it. Contact with the department that produced the document reveals that feedback received on this publication is generally positive, but that feedback and queries have been less than expected, suggesting a low awareness among the target audience, maybe the

Table 4. Barriers to supply.

\section{Barrier}

Frequency (\%)

Lack of awareness of opportunities 78

Difficulty getting on to approved supplier list

Lack of knowledge of the procurement process

Lengthy and complex tendering process

Overly prescriptive requirements

Insufficient consultation prior to tender

Scale of contract unsuitable for SMEs

Too much focus on cost

Restrictive requirements, eg environmental 
Table 5. Additional barriers identified by SMEs.

$\begin{array}{ll}\text { Category } & \begin{array}{l}\text { Explanation } \\ \text { A concern that only those with a } \\ \text { strong track record, that is, } \\ \text { experience, stand a chance of } \\ \text { bidding successfully } \\ \text { Excessive and prohibitive amounts } \\ \text { of administration and paperwork } \\ \text { involved }\end{array} \\ \text { Bureaucracy } & \begin{array}{l}\text { Public sector organizations are } \\ \text { seen to be risk-averse and } \\ \text { reluctant to accept innovation } \\ \text { Inertia }\end{array} \\ \text { Lack of training and qualifications } \\ \text { for efficient and effective } \\ \text { procurement }\end{array}$

Contact and accessibility Difficult to establish the appropriate person to contact.

result of a lack of awareness of the events at which the booklet is publicized.

The opportunity to add further barriers and comment was taken by 39 respondents. Most of the comments can be categorized under five headings. The five categories and a brief explanation are listed in Table 5 and discussed more fully below.

The administrative burden features strongly. Quayle and Quayle (2000, p 268) recognized that:

institutions which sponsor their activities with public funds and donations are forced to ensure transparency and accountability of purchases, thus resulting in selection procedures which involve use of competitive bidding and formal bid evaluation committees consisting of many members.

The evidence of these practices also suggests an approach to procurement that is more adversarial than partner-based, which is supported by other research evidence (Burnes and Anastasiadis, 2003). Whilst many of the survey respondents in this study acknowledged in their comments the need for accountability and recognized the administrative requirements associated with this, the concern was the apparent disadvantage this places upon small businesses, as the following comment demonstrates:

The amount of pre-contract work required to win PFI contracts is excessive and prohibitive for small/medium businesses who cannot commit such expense to risk, therefore few bother.

The time and other resource costs associated with both the pre-tendering and tendering processes appear disproportionate to the scale and value of the contract, as the following respondent observes:

I have personally found that some - but not all - public sector agencies require an unreasonable and unwarranted amount of bureaucratic hoops to be gone through - which are completely unrealistic in the light of the size/nature of the contract on offer.

One respondent even suggested that the burden of 'red tape' negated profit margins, although the continuity of cash flow was welcomed.

The public sector was also accused of inertia, of being risk-averse and demonstrating an unwillingness to accept new ideas. Respondents identified 'rigidity of process', employees as 'reluctant to accept innovation and flexibility' and that 'there are still a lot of overly cautious individuals'. These observations are interesting, given the extent of change in public sector organizations over recent years, demonstrated by challenges to the status quo under initiatives such as Best Value, which have sought to encourage open and flexible attitudes (DETR, 1998). However, other studies support the view that risk taking is not encouraged (Quayle and Quayle, 2000) and have suggested that risk-averse behaviour by public sector purchasing staff may be partly explained by the need for public scrutiny (Murray, 1999).

SMEs also identified 'a reluctance to open the system to new providers' and, a related concern, the need to demonstrate a good track record. This does not match the open competition advocated under the traditional, or adversarial, approach to procurement and is unlikely to produce value for money. Several respondents felt that this attitude specifically hindered newer businesses, which were unable to establish a track record if not given a first opportunity. There was also a claim that established relationships might not deliver the best service, as identified below:

[They] focus upon past history and not ability. As a company we have the ability and skills to perform a contract but are usually rejected because of historical experience. We find that most public sector procurement officers are under trained or not technically qualified to deal with public procurement. As a general rule we have found them to take the easiest procurement, rather than the best 'fit for purpose' contract bid.

The quote above also refers to inadequate training. Another respondent described purchasing methods as 'inept'. However, Erridge and Greer (2002), in their study evaluating UK central government procurement policy, found the skills of procurement staff to be improving, and also that "with greater skills and expertise, the capacity and confidence of procurement staff also increased, creating more willingness to adopt innovative procedures' (Erridge and Greer, 2002, p 513). Smith and Hobbs, in a research report for the Small Business Service, also found that the 'skill of professional staff has increased over the last years' (Smith and Hobbs, 2002, executive summary). Improved skills are to be welcomed and should contribute towards more 
effective purchasing. However, other improvements may be required to enhance decision making. More concern was expressed about the attitudes and perceived unfairness of decision makers. Such criticism is not restricted to PSOs. Briscoe et al (2001, p 253) found that attitudes, as well as inadequate skills 'can pose effective barriers to the efficient operation of supply chains' within the construction industry. In particular, there is a view that PSOs 'make biased decisions' in favour of larger companies. One respondent states:

I believe that local public sector organisations have the perception that local SMEs cannot cope with their business requirements.

This is echoed by the SBC's claim of 'anecdotal evidence that in practice larger companies are instinctively preferred, despite the most recent guidance issued to the public sector' (SBC, 2002, p 11). One of the survey respondents offered a more neutral opinion, stating that:

There is the continuing lack of understanding from both sides of the other's needs and requirements.

Finally the problem of identifying the appropriate contact was raised. This is likely to be made more difficult as public sector service delivery mechanisms become more fragmented and devolved.

\section{Overcoming barriers}

The same respondents were next asked for their views on how barriers might be overcome. Forty-four firms put forward comments. Not surprisingly, the suggestions revolved around the main barriers just identified. Ten businesses were keen to see more dialogue between public bodies and small businesses, either on a one-toone basis or with representative organizations such as the Small Business Forum, in order to provide opportunities for both an exchange of views and a means for small firms to contribute their opinions into the process. However, there was little recognition by the SME respondents of the additional resource demands this might make, already identified as a challenge in the procuring of public sector contracts.

The need to improve upon the provision of information was separately identified. Information was requested on contacts and opportunities. Firms want to be able to establish personal contact with those people in a position 'to make decisions or promote change'. The personal contact is seen by some to be important:

The only progress is through personal introductions and possibly networking with the decision makers.

However, the trend may be in the opposite direction as government promotes e-procurement (OGC, 2002a). Through e-procurement it is looking to deliver 'services in the fastest most appropriate way possible by optimum use of technology, which allows customers to order products and services online through several catalogues' (OGC, 2003, p 7). Firms also want opportunities to be better publicized, with more information about requirements and procedures. This will put them in a better position to be able to gauge whether they feel capable of meeting the requirements, and therefore whether it is worth committing resources to the tendering process. Most of the comment was restricted to identification of the need for information rather than suggesting specific communication methods that might prove more successful than current approaches. Although only $19 \%$ of respondents were aware of information or events to encourage SMEs to tender for public sector contracts, their experience demonstrated a wide range of methods being adopted by PSOs - for example: trade journals, magazines, newspapers, seminars, meet-the-buyer events and Websites.

Many comments addressed the desire to see a reduction in bureaucracy, seen to be unfair to small firms, or at least for PSOs to be more flexible about administrative requirements. Whilst there was an acknowledgment of the need for procedures to support accountability, there was a feeling that they were possibly outdated and in need of revision. Suggestions included reducing requirements for lower-value orders, devising simple reference forms to allow firms successfully completing a contract to work for other organizations on similar types and scales of projects, and also tailoring the administrative requirements according to the scale and complexity of the goods/ service to be supplied. Some recent developments appear to be moving in the right direction. A statement by the OGC (2002b) sets out its intention to increase the number of collaborative supply contracts, which should provide access to 'pre-vetted' suppliers. These are suppliers who would not need to tender for every contract, having previously competed for business and met rigorous criteria. However, the scheme is applicable to all suppliers and it is not clear how appropriate it may be for SMEs. As stated previously, collaborative procurement is about increasing purchaser power through the use of large-scale contracts.

Not only was concern expressed about the scale of contracts, but also their length. Respondents indicated reluctance to enter into long-term contracts that were seen as inflexible and rigid. However, such an attitude puts SMEs at a disadvantage in the move towards longer-term partnership supply. There was also a view that the different characteristics of SMEs should be recognized and attitudes and requirements adjusted. Specialized assistance, discriminatory tendering and local sourcing were all mentioned, although the scope 
for many of these activities is restricted by European Procurement Directives.

Whilst knowing who to contact was perceived as a difficulty, several suggested that barriers would be fewer with greater decentralization of the procurement process, especially moving away from nationally based systems. One respondent suggested that SMEs should organize themselves into consortia. The survey did elicit views on consortia. Fifteen per cent of all respondents already had experience of supplying goods/services as part of a consortium, and $69 \%$ of the remaining $85 \%$ stated that they would be willing to consider it in the future. However, such developments may be difficult to implement without further advice or the intervention of other agencies.

\section{Advantages of SME supply}

The final element of the survey sought the views of SMEs on the advantages that they felt they could offer to PSOs. Seventy-five per cent of firms indicated that SMEs had something positive to offer, identifying 18 benefits in total. Table 6 shows the most frequent responses. Seven benefits have been identified by UK government: bringing greater competition to the marketplace, lower cost, innovation, responsiveness, flexibility, quality of service and specialism (OGC and SBS, 2001a). The survey responses show considerable parallels with those identified by the government.

Whilst the government explanation of 'quality of service' includes a customer-focus aspect, many SMEs in this survey were keen to identify these as separate benefits, which is reflected in the table. Also price and value for money, the latter focusing on efficiency and effectiveness, were distinguished by several respondents. Innovation, one of the benefits identified by government, is recognized by only $9 \%$ of respondents. This seems surprisingly low, especially given the earlier criticisms of PSOs for using overly prescriptive requirements, which act to inhibit innovation, and for their caution and reluctance to accept new ideas and innovation.

\section{Implications of the findings}

The evidence from those SMEs that participated in the survey suggests that they consider themselves to be disadvantaged, when compared with larger organizations, in their desire to become suppliers to PSOs. Whether this is a result of real or perceived barriers cannot at this stage be asserted and requires further investigation. However, accepting the existence of barriers, the concern for both parties is whether and how these barriers can be overcome. In the preceding discussion, SMEs suggested a number of ways forward.
Table 6. Advantages of SME suppliers.

\begin{tabular}{lcc}
\hline Benefit & $\begin{array}{c}\text { Number of respondents } \\
\text { (from 82) }\end{array}$ & $\begin{array}{c}\text { Frequency } \\
\%\end{array}$ \\
$\begin{array}{l}\text { Flexible } \\
\text { More personable service }\end{array}$ & 46 & 56 \\
$\begin{array}{l}\text { Responsive, including } \\
\text { speedy response }\end{array}$ & 34 & 41 \\
$\begin{array}{l}\text { High quality, including } \\
\text { technical ability }\end{array}$ & 34 & 41 \\
$\begin{array}{l}\text { Customer-focused } \\
\text { Competitive price }\end{array}$ & 31 & 38 \\
$\begin{array}{l}\text { Value for money } \\
\text { Local knowledge }\end{array}$ & 24 & 29 \\
Highly supervised/owner- & 23 & 28 \\
$\quad$ manager contact & 8 & 11 \\
Innovative/initiative & 7 & 10 \\
Opportunity to support & 7 & 9 \\
local economy & 7 & 9 \\
\hline
\end{tabular}

However, closer examination suggests that these will provide challenges for both the SME and government sectors.

For small business, one of the main challenges is the resource commitment that would be required to engage in meaningful dialogue with public sector contacts. This may be a role for small business representative organizations, or alternatively it may act as a driver towards consortium-based approaches. The consortium has other advantages, placing SMEs in a stronger negotiating position and enabling larger-scale contracts to be contemplated. However, given the low level of experience of working under such arrangements, it is likely that support would be required to advise or facilitate such arrangements. Further work needs to be done to ascertain how this support might best be provided: by government, by small business representative bodies, or by professional or industry association. Small business also needs to consider its preferred method of working: can it identify methods of communication, for example, that could be employed by PSOs and that would prove more successful in effectively reaching the target SME audience?

For government, the nature of its business produces conflict. Requirements to demonstrate accountability and transparency in the use of public monies influence the extent of the administrative burden. However, some current developments appear to demonstrate an element of flexibility that may offer some hope for the possibility of easing the regressive burden upon SMEs. Other challenges are presented by the impact of other procurement-related policy initiatives. The emphasis upon e-procurement appears to be in conflict with the desire expressed by SMEs for further personal contact, whilst the trend towards greater collaboration by PSOs in their purchasing is leading to a position of even greater buyer 
power and larger-scale contracts, both placing individual small and medium-sized firms at a greater disadvantage.

\section{Conclusion}

Growing attention is being given by the UK government to the supply of public sector organizations by small businesses. Government policy is based upon a recognition of the importance of the SME sector to the UK economy and also an acknowledgment that small businesses can provide benefits in the supply of goods and services that can enhance its own service delivery. However, there is a concern that SMEs face barriers placing them at a disadvantage in tendering for public sector contracts, resulting in an SME tendering deficit. Therefore government policy has led to initiatives to encourage PSOs to use SME suppliers, and has provided advice to both sectors. The issue is receiving increasing attention amongst government agencies, with a recent report being critical of government efforts (BRTF and SBC, 2003).

This study attempts to further the debate by providing an SME view on the question of whether UK public sector purchasing policies are supporting SMEs. The SME perspective was obtained by means of a postal survey, which has presented a broad overview of SME experiences. Over 100 SMEs located in Teesside in the north-east of England made up the sample. However, it is felt that the evidence and discussion should have a general relevance to all interested parties.

The empirical evidence determined that the majority of SMEs surveyed felt that barriers did exist, despite $60 \%$ currently supplying PSOs. The nature of the barriers and SME suggestions for overcoming them present a challenge to both government and small business organizations and agencies. Government needs to address policy conflicts in particular, whilst small business must consider how best to deal with additional resource requirements, determine a preferred communication strategy with PSOs and consider new ways of working. Only then can both sectors move towards the advantages that they both recognize can result from closer supply relationships.

The way in which these challenges might be addressed would benefit from further investigation. Further exploration of the SME perspective is required to provide a greater understanding of the nature of the barriers faced, and in particular to consider whether these barriers are real or perceived, as this will have a bearing upon actions to be taken. Additionally there is a need to consider the public sector viewpoint and to examine more comprehensively the impact of procurement-related policies upon PSOs and their ability to purchase from the SME sector.

\section{References}

Axelsson, B., Laage-Hellman, J., and Nilsson, U. (2002), 'Modern management accounting for modern purchasing', European Journal of Purchasing \& Supply Management, Vol 8, pp 53-62.

BRTF and SBC (2003), Supporter and Customer? Better Regulation Task Force and Small Business Council, London.

Briscoe, G., Dainty, A. R. J., and Millett, S. (2001), 'Construction supply chain partnerships: skills, knowledge and attitudinal requirements', European Journal of Purchasing \& Supply Management, Vol 7, No 4, pp 243-255.

Burnes, B., and Anastasiadis, A. (2003), 'Outsourcing: a publicprivate sector comparison', Supply Chain Management: An International Journal, Vol 8, No 4, pp 355-366.

Business Link (2003), Selling to Government, Website: http:// www.businesslink. gov.uk/bdotg/action/, accessed 4 December 2003.

Cabinet Office (1984), Government Purchasing: A MultiDepartment Review of Government Contract and Procurement Procedures, Cabinet Office, London.

DETR (1998), Modern Local Government. In Touch with the People, White Paper, July, DETR, London.

Erridge, A., and Greer, J. (2002), 'Partnership and public procurement: building social capital through supply relations', Public Administration, Vol 80, No 3, pp 503-522.

Gershon, P. (1999), Review of Civil Procurement in Central Government, HM Treasury, London.

HM Treasury, (1995), Setting New Standards: A Strategy for Government Procurement, HM Treasury, London.

HM Treasury/Cabinet Office, (1998), Efficiency in Civil Government Procurement, HM Treasury, London.

Lamming, R. (1993), Beyond Partnership. Strategies for Innovation and Lean Supply, Prentice Hall, Hemel Hempstead.

McAleer, E., Mclvor, R., Humphreys, P., and McCurry, L. (2000), 'What multinational corporations with manufacturing plants in Northern Ireland and the Republic of Ireland are demanding from their suppliers', Journal of Small Business and Enterprise Development, Vol 7, No 4, pp 363-373.

Morrissey, B., and Pittaway, L. (2004), 'A study of procurement behaviour in small firms', Journal of Small Business and Enterprise Development, Vol 11, No 2, pp 254-262.

Murray, J. G. (1999), 'Local government demands more from purchasing', European Journal of Purchasing \& Supply Management, Vol 5, No 1, pp 33-42.

Murray, J. G. (2002), 'New roles for purchasing: researchers, detectives, teachers, doctors and architects', The International Journal of Public Sector Management, Vol 15, No 4, pp 307315.

National Audit Office (1999), Modernising Procurement, National Audit Office, London.

OGC (2000), Alignment Review, Office of Government Commerce, London.

OGC (2001), The Code of Good Customer Practice. Working With Suppliers, Office of Government Commerce, London.

OGC (2002a), eProcurement: Cutting Through the Hype. A Guide to eProcurement for the Public Sector, Office of Government Commerce, London.

OGC (2002b), Harnessing Public Sector Buying Power Produces Major Gains For Taxpayers, Press Release, 10 December, Office of Government Commerce, London.

OGC (2003), Delivering Your Agenda, Office of Government Commerce, London.

OGC and Business Link (2003), Supplying Government, Website: http://www.supplyinggovernment.gov.uk/ WhatGovBuys.asp, accessed 7 January 2004.

OGC and SBS (2001a), Smaller Supplier Better Value? Office of Government Commerce and Small Business Service, London.

OGC and SBS (2001b), Tendering for Government Contracts. A 
Guide for Small Businesses, Office of Government Commerce and Small Business Service, London.

Parker, D., and Hartley, K. (1997), 'The economics of partnership sourcing versus adversarial competition: a critique', European Journal of Purchasing \& Supply Management, Vol 3, No 2, pp 115-125.

Quayle, M. (2002), 'Purchasing in small firms', European Journal of Purchasing \& Supply Management, Vol 8, No 3, pp 151159.
Quayle, M., and Quayle, S. (2000), 'The impact of strategic procurement in the UK further and higher education sectors', The International Journal of Public Sector Management, Vol 13, No 3, pp 260-284.

SBC (2002), Second Annual Report 2001/02, Small Business Council, London.

Smith, P., and Hobbs, A. (2002), SMEs \& Public Sector Procurement, research report prepared for Small Business Service, Shreeveport Management Consultancy, London. 